\title{
OPTICAL AND ELECTRICAL PROPERTIES FOR DETERMINING HARVEST TIME OF BEAN AND PEA PODS
}

\author{
A.E. El-Raie ${ }^{1}$, Y.A. Bader ${ }^{2}$, H.E. Hassan ${ }^{3}$, and R. Khamis ${ }^{4}$
}

\begin{abstract}
The main objectives of this research are to use visible laser to determine the optimal harvest time of green beans (Phaseolus vulgaris L. var Paulista) and Sweet peas (Pisum Sativum L. var Sugar Lays) with its optical and electrical properties at different ages. Obtained results are summarized as follows: 1) The values of light reflection intensity increased by using He-Ne laser (632.8 nm) for ages of green bean and green peas, meanwhile these values decreased by using $\mathrm{He}-\mathrm{Ne}$ laser (543.5nm); 2) The values of electrical signals were increased by using He-Ne laser (632.8 nm) and decreased by using He-Ne laser (543.5 nm) for ages of green pean and pea pods.; and 3) There were relationships between intensity of light and electrical reflections by using two $\mathrm{He}-\mathrm{Ne}$ laser as a function of the green beans and pea pods age. The He-Ne laser with wavelength $632.8 \mathrm{~nm}$ was suitable high reflection from green bean and sweet pea pods at ages (maturity stages) about 22 and 18 days, respectively (optimal harvest time) from the appearance of the flower pods.
\end{abstract}

Keywords: Laser, Green beans, Green peas, Optic, Electrical properties.

\section{INTRODUCTION}

I f a laser beam is directed at a tissue (living surface), it may be reflected back to the source or to another undesired surface. If reflectance is adequately controlled and the light enters the tissue, the ultimate event affecting the tissue is absorption of the light. However, the tissue itself can scatter the light. (Ahn and Moore, 1992).

1- Prof. Dr., Agric. Eng. Dep., Fac. of Ageic., Cairo Univ., Egypt.

2\&3- Prof. Dr.,\& Assoc. Prof., Nat. Inst. of Laser Enhanced Sc., Cairo Univ., Egypt.

4- Res., Agric. Eng. Res. Inst, Agric. Res Center, Dokki, Egypt. 
Slaughter (1995) investigated a non-destructive optical method for determining the internal quality of intact peaches and nectarines. The method, based upon visible and near-infrared spectrophotometric techniques, was capable of simultaneously predicting the soluble solids content $(\mathrm{r}=0.92)$, sucrose content $(\mathrm{r}=0.87)$, sorbitol content $(\mathrm{r}=0.88)$, and chlorophyll A content ( $\mathrm{r}=0.97$ ) of intact peaches and nectarines, and required no sample preparation. The visible and NIR-spectroscopy could be used to measure non-destructively the internal quality of peaches and nectarines.

Salunkhe and Kadam (1998) stated that the harvest time is determined largely by the appearance of the pods. These should be well filled with tender young peas and changing in color from dark to light green. The harvesting should be made when the peas are still in prime condition, but without sacrificing the yield.

Zur et al. (2000) suggested normalization of the leaf absorbance spectra $\left(\mathrm{A}_{\lambda}\right)$ to the red $\mathrm{Chl}$ absorbance at $678 \mathrm{~nm}\left(\mathrm{~A}_{678}\right)$. They stated that the reflectance around $520 \mathrm{~nm}$ correlates closely with carotenoids content in yellow to green leaves. Thus, this spectral feature at $520 \mathrm{~nm}$ could be used as a measure of carotenoids content in green leaves and plant.

Hassan (2002) showed that the optical properties were determined for the soundness and blemishes of oranges using helium-Neon (He-Ne) with wavelength $632.8 \mathrm{~nm}$ and Argon laser with wavelengths of 514, 496 and $488 \mathrm{~nm}$, respectively and power of $10 \mathrm{~mW}$. The He-Ne laser is suitable to use because it gives high reflection and a criterion to identify defects for each variety of oranges.

Corgan (2004) stated that beans (snap) harvest when full-sized pods, beans about $1 / 4$ of their mature size, before constrictions in the pod are evident. And beans (lima) harvest when well filled, but not over mature. Seeds should be green and tender. But peas (English) harvest when bright green, pods fully developed but still tender, and before seeds develop fully.

Gitelson and Merzlyak (2004) stated that reciprocal reflectance $\left(\mathrm{R}_{\lambda}\right)^{-1}$ in the spectral range $\lambda$ from 520 to $550 \mathrm{~nm}$ and from 695 to $705 \mathrm{~nm}$ related closely to the total pigment content (chlorophylls + carotenoids) in leaves of all species. 
El-Raie et al. (2005) found that reflection intensity using laser beam $632.8 \mathrm{~nm}$ was higher than intensity reflection using laser beam $543.5 \mathrm{~nm}$ in the stages 3, 4, 5 and 6 of strawberry. There is reverse relation between reflection and absorption percentages, where the reflection increased from stage 1 to 6 , while the absorption percentage decreased. By increasing the quantity of optical reflection, the electrical signals increased using laser with wavelength $632.8 \mathrm{~nm}$, because this wavelength was more compatible with color wavelength of mature stages strawberry.

Gitelson et al. (2006) suggested a model, using reflectance in three spectral bands has been applied for non-destructive assessment of total chlorophyll, carotenoid and anthocyanin contents in plant leaves. Only four spectral bands are required for three pigments retrieval: $510-520 \mathrm{~nm}$ (carotenoids), 540- $560 \mathrm{~nm}$ (anthocyanins), 690-710 $\mathrm{nm}$ (total chlorophyll) and 760-800 $\mathrm{nm}$.

The objectives of this study are to measure and determine the following: 1- optical and electrical properties of green beans and peas pods at different ages using visible laser, 3- suitable wavelength to determine the optimal harvest time of pods, and 4- establish a criterion to identify optical and electrical properties of pods for sorting and grading using visible laser.

\section{MATERIAL AND METHODS}

The samples of green beans (Phaseolus vulgaris L. var Paulista) and sweet pea's or green pea's (Pisum Sativum L. var Sugar Lays) pods were obtained from green house of the Central Laboratory for Agricultural Climate, Agricultural Research Center (ARC) at Dokki, Giza, ARE.

\section{The experimental setup:}

The experimental setup (Fig. 1 and 2 ) was developed and assembled in the laboratory of laser applications in agricultural engineering, (NILES), Cairo University and consists of laser source, filter, lenses, holders, digital luxmeter, photovoltaic cell, and avometer.

He-Ne lasers: The helium-neon (He-Ne) lasers \{Red (05-LHP-151, U.S.A) and Green (05-LGR-173, U.S.A)\} in the visible light (wavelengths 632.8 and $543.5 \mathrm{~nm}$ ) with power 8 and $4 \mathrm{~mW}$ respectively, were used in the present work as light sources. 
Filter: The filter (50510, U.S.A) was a calibrated metallic neutral density filter to fill a variety of attenuation needed in the Ultra-violt, visible and near infrared. It was position was in front of laser beam (He-Ne red) to control its power.

Lens: A convex silica glass lens of $100 \mathrm{~mm}$ focal length with diameter $75 \mathrm{~mm}$ was used. The lens was used with angle $45^{\circ}$ to focus the reflected light collected from the pod surface one time onto the luxmeter detector and other onto photovoltaic cell connected with an avometer.

Holders: Holders fabricated from copper were used to hold lens, filter, sample, luxmeter detector and photo cell.

digital luxmeter (Lx-101, Japan) with high accuracy and sensitivity was used to measure the intensity of light reflection from pods surface.

Photovoltaic cell: Photovoltaic cell length $60 \mathrm{~mm}$ and width $40 \mathrm{~mm}$ with efficiency $23 \%$. It mounted on a holder which allowed the cell to move at any direction. The intensity of the reflected light is transformed to voltage by photovoltaic cell which was transferred to an avometer.

AVO meter (Digital millimeter mod. CDA-701, Japan) was used to measure the electrical signal with volt resulted from converting the reflection of light from pods surface by a photovoltaic cell.

\section{Laboratory tests:}

The intensity of light reflection from pods surfaces was carried out using setup Fig. (1 ). Pods of green beans and sweet peas at different ages were exposured to the laser and detector of luxmeter device to measure the intensity of light from the pods. The electrical signal with milli volt was obtained by using setup Fig. (1). The AVO meter device received the reflectance light from the pods of green beans and sweet peas at different Ages. The absorption of pods was calculated from the following equation according to the law of conservation of energy:

$$
\mathbf{I}=\mathbf{R}+\mathbf{A}
$$

Where: $\mathrm{I}$ is the incident beam, lux, $\mathrm{R}$ - reflective beam, lux; and A - absorptive beam, lux. 

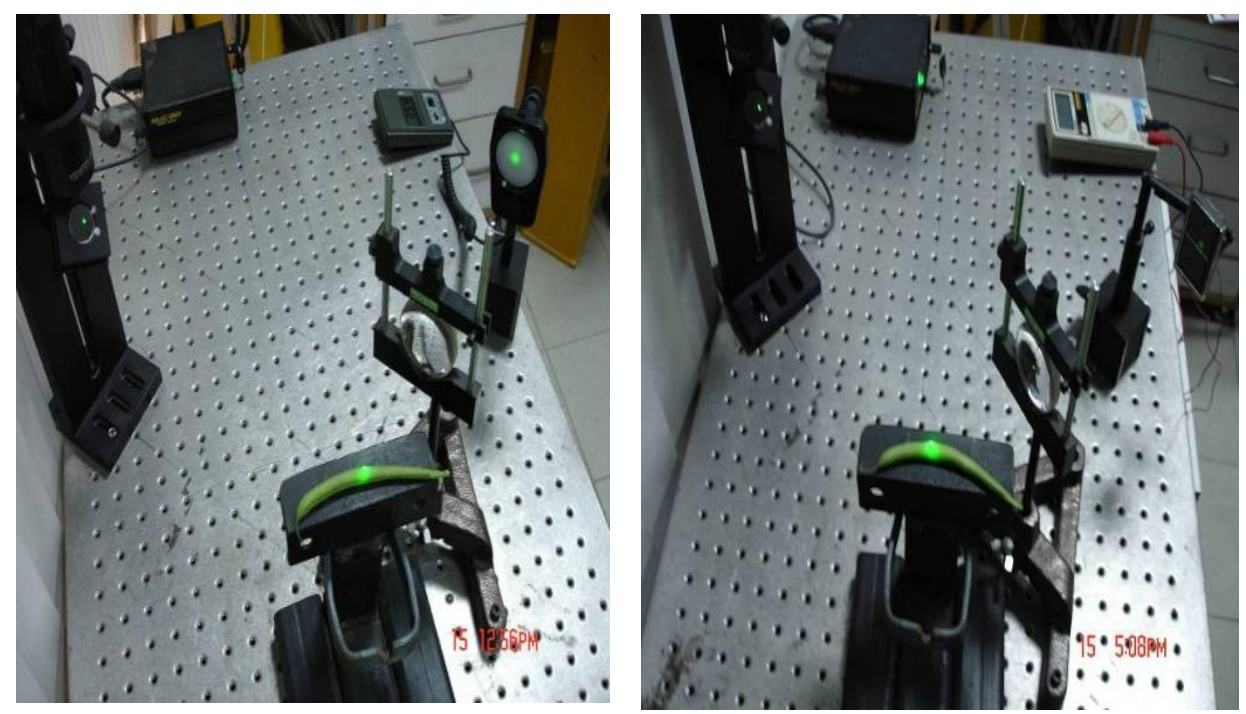

Fig. (1): Experimental setup for measuring the intensity of light (A) and electrical (B) reflections from the pods using visible laser.

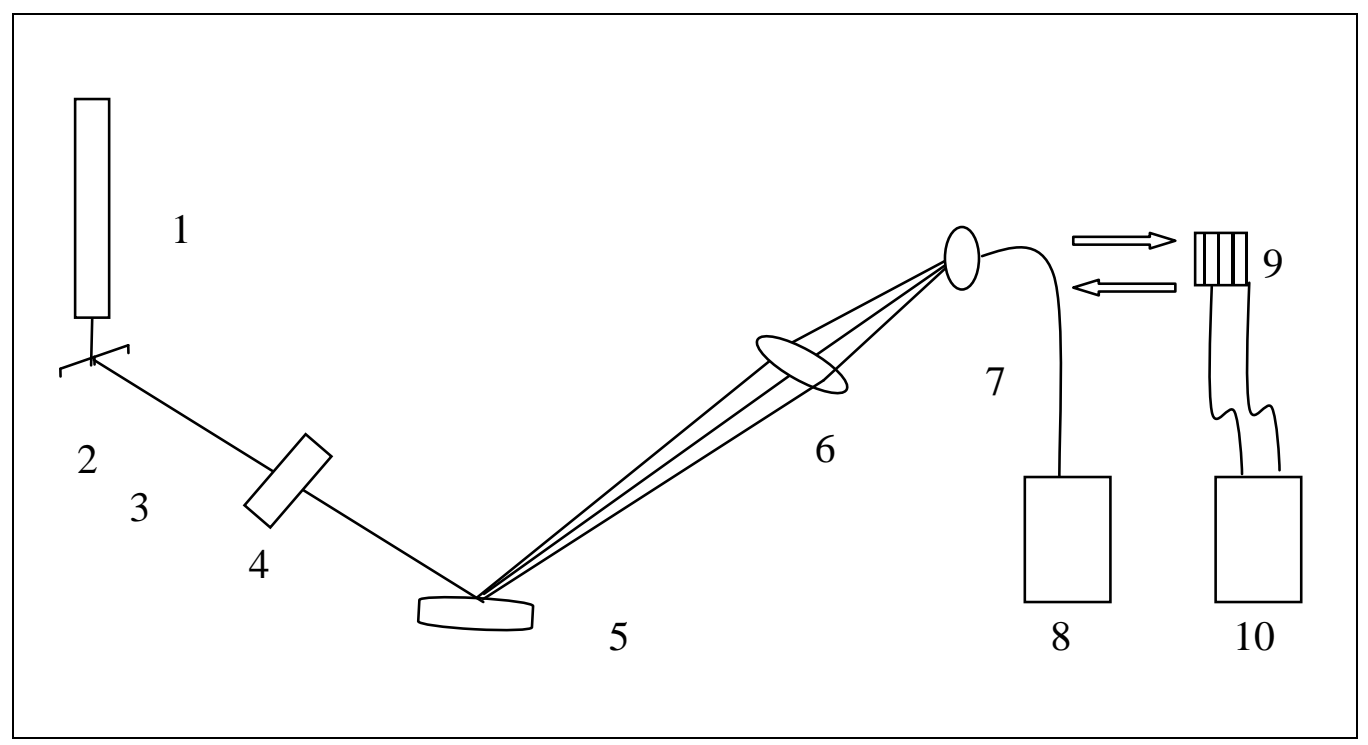

1 : Laser source; 2 : Mirror; 3 : Laser beam; 4 : Filter; 4 : Filter; $5:$ Sample; 6 : Convex lens; 7 : Detector; 8: Lux meter; 9 : Photovoltaic cell; 10: Avo meter.

Fig. (2): The assembled setup for light and electrical reflections. 


\section{RESULTS AND DISCUSSION}

\section{Optical Properties:}

When light is incident on any material, it may be reflected, transmitted through it, and absorbed within it. Green beans and sweet pea pods were exposed to helium neon laser with two wavelengths 632.8 and $543.5 \mathrm{~nm}$. The experimental setup was adjusted at incident angle equal to reflected angle $\left(45^{\circ}\right)$ to obtain high reflections.

\section{1. green bean pods:}

Table (1) illustrates that the values of intensity of light reflection were decreased by using He-Ne laser (wavelength $543.5 \mathrm{~nm}$ ) compared with the other wavelength $(632.8 \mathrm{~nm})$. It is clear that when the ages of pods increase, the intensity of light reflection increased (direct proportion) by using He-Ne laser (wavelength $632.8 \mathrm{~nm}$ ). However, when the pods age increases, the intensity of reflection light decreased (inverse proportion) by using He-Ne laser (wavelength $543.5 \mathrm{~nm}$ ).

The average values of light intensity of reflections from pods using $\mathrm{He}-$ Ne laser (wavelength $632.8 \mathrm{~nm}$ ) were smaller than the average values when using He-Ne laser (wavelength $543.5 \mathrm{~nm}$ ) at each age. Using the mean values shown in Table (1), the following general equations were deduced to express the relationships between intensity of reflection by using laser at wavelength $632.8 \mathrm{~nm}\left(\mathrm{I}_{632.8}\right)$ and intensity of reflection by using laser at wavelength $543.5 \mathrm{~nm}\left(\mathrm{I}_{543.5}\right)$ of green bean pods at different ages from the appearance of the pods.

For pods at 10 days (first age):

$\mathrm{I}_{632.8}=1.825 \mathrm{I}_{543}$

For pods at 22 days:

$\mathrm{I}_{632.8}=0.671 \mathrm{I}_{543}$

For pods at 31 days (last age):

$\mathrm{I}_{632.8}=0.371 \mathrm{I}_{543.5}$

Generally, the following equations summarize the relationships between $\mathrm{I}_{632.8}$ and $\mathrm{I}_{543.5}$ as a function of the pods age (A).

$\mathrm{I}_{632.8}=7.213+1.388 \mathrm{~A}, \mathrm{R}^{2}=0.824, \mathrm{~F}_{\text {Regression }}=3731$

$\mathrm{I}_{543.5}=46.948-0.935 \mathrm{~A}, \mathrm{R}^{2}=0.705, \mathrm{~F}_{\text {Regression }}=1902$ 
Table (1): The intensity of reflection (Lux) from green bean pods at different ages using He-Ne laser with two wavelengths.

\begin{tabular}{|c|c|c|c|c|c|c|}
\hline \multirow{3}{*}{$\begin{array}{l}\text { Pods } \\
\text { age, } \\
\text { day }\end{array}$} & \multicolumn{6}{|c|}{ He-Ne laser } \\
\hline & \multicolumn{3}{|c|}{ (wavelength $632.8 \mathrm{~nm}$ ) } & \multicolumn{3}{|c|}{ (wavelength $543.5 \mathrm{~nm}$ ) } \\
\hline & $\begin{array}{c}\text { Range, } \\
\text { Lux }\end{array}$ & $\begin{array}{c}\text { Mean } \\
\text { value, } \\
\text { Lux }\end{array}$ & $\begin{array}{l}\text { Mean } \\
\text { intensity of } \\
\text { reflections, } \\
\text { Lux }\end{array}$ & $\begin{array}{c}\text { Range, } \\
\text { Lux }\end{array}$ & $\begin{array}{c}\text { Mean } \\
\text { value, } \\
\text { Lux }\end{array}$ & $\begin{array}{c}\text { Mean } \\
\text { intensity of } \\
\text { reflections, } \\
\text { Lux }\end{array}$ \\
\hline 10 & $16-24$ & 20.0 & $20.0 \pm 4.0$ & $27-46$ & 36.5 & $36.5 \pm 9.5$ \\
\hline 13 & $15-30$ & 22.5 & $22.5 \pm 7.5$ & $25-45$ & 35.0 & $35.0 \pm 10.0$ \\
\hline 16 & $21-36$ & 28.5 & $28.5 \pm 7.5$ & $23-43$ & 33.0 & $33.0 \pm 10.0$ \\
\hline 19 & $27-45$ & 36.0 & $36.0 \pm 9.0$ & $20-39$ & 29.5 & $29.5 \pm 9.5$ \\
\hline 22 & $30-49$ & 39.5 & $39.5 \pm 9.5$ & $17-36$ & 26.5 & $26.5 \pm 9.5$ \\
\hline 25 & $32-51$ & 41.5 & $41.5 \pm 9.5$ & $15-32$ & 23.5 & $23.5 \pm 8.5$ \\
\hline 28 & $36-56$ & 46.0 & $46.0 \pm 10.0$ & $13-28$ & 20.5 & $20.5 \pm 7.5$ \\
\hline 31 & $38-59$ & 48.5 & $48.5 \pm 10.5$ & $10-26$ & 18.0 & $18.0 \pm 8.0$ \\
\hline
\end{tabular}

The equations ( 4 and 5) indicate that the age affects the intensity of reflection by using laser at wavelength $632.8 \mathrm{~nm}$ more than the intensity of reflection by using laser at wavelength $543.5 \mathrm{~nm}$.

Fig. (4) shows an inverse relationship between the percentages of reflection and absorption at different ages of green beans. The percentages of light absorption are higher than the percentages of light reflection. It is noticed that the percentages of reflection increased gradually but the absorption decreased from 10 to 31 days old by using He-Ne laser with wavelength $632.8 \mathrm{~nm}$.

By using He-Ne laser with wavelength 543.5nm (Fig. 5), the reflection percentages of green bean pods decreased gradually across pods ages. Meanwhile, the absorption percentages increased gradually.

\subsection{Sweet pea pods:}

Table (2) indicate that the range values of the light intensity of sweet pea pods using $\mathrm{He}-\mathrm{Ne}$ at $632.8 \mathrm{~nm}$ were increased, while the range values of the intensity of light using $\mathrm{He}-\mathrm{Ne}$ laser at $543.5 \mathrm{~nm}$ were decreased at 
pods ages 6 to 33 days. It is noticed that when the age of pods increased, the intensity of light reflection increased (direct proportion) by using HeNe laser (wavelength $632.8 \mathrm{~nm}$ ). When the pods age increased, the intensity decreased (converse proportion) by using $\mathrm{He}-\mathrm{Ne}$ laser (wavelength $543.5 \mathrm{~nm}$ ). The ranged values of light intensity of reflections using He-Ne laser (wavelength $632.8 \mathrm{~nm}$ ) were smaller than the ranged values of light intensity of reflections using $\mathrm{He}-\mathrm{Ne}$ laser (wavelength $543.5 \mathrm{~nm}$ ). So He-Ne laser with wavelength $632.8 \mathrm{~nm}$ is the suitable beam resulting high reflections from pods.

Table (2): The intensity of reflection (Lux) from sweet pea pods at different ages using He-Ne laser with two wavelengths.

\begin{tabular}{|c||c|c|c|c|c|c||}
\hline \multirow{3}{*}{$\begin{array}{c}\text { Pods } \\
\text { age, } \\
\text { day }\end{array}$} & \multicolumn{7}{|c|}{$\begin{array}{c}\text { Havelength 632.8 nm) } \\
\text { Lux }\end{array}$} & $\begin{array}{c}\text { Mean } \\
\text { value, } \\
\text { Lux }\end{array}$ & $\begin{array}{c}\text { Mean intensity } \\
\text { of reflections, } \\
\text { Lux }\end{array}$ & $\begin{array}{c}\text { Range, } \\
\text { Lux }\end{array}$ & $\begin{array}{c}\text { Mean } \\
\text { value, } \\
\text { Lux }\end{array}$ & $\begin{array}{c}\text { Mean } \\
\text { intensity of } \\
\text { reflections, } \\
\text { Lux }\end{array}$ \\
\hline \hline 6 & $10-16$ & 13.0 & $13.0 \pm 3.0$ & $29-35$ & 32 & $32 \pm 3$ \\
\hline 9 & $13-19$ & 16.0 & $16.0 \pm 3.0$ & $24-31$ & 27.5 & $27.5 \pm 3.5$ \\
\hline 12 & $15-22$ & 18.5 & $18.5 \pm 3.5$ & $21-29$ & 25 & $25 \pm 4$ \\
\hline 15 & $17-26$ & 21.5 & $21.5 \pm 4.5$ & $19-28$ & 23.5 & $23.5 \pm 4.5$ \\
\hline 18 & $19-29$ & 24.0 & $24.0 \pm 5.0$ & $16-26$ & 21 & $21 \pm 5$ \\
\hline 21 & $22-32$ & 27.0 & $27.0 \pm 5.0$ & $14-25$ & 19.5 & $19.5 \pm 5.5$ \\
\hline 24 & $23-35$ & 29.0 & $29.0 \pm 6.0$ & $13-24$ & 18.5 & $18.5 \pm 5.5$ \\
\hline 27 & $25-37$ & 31.0 & $31.0 \pm 6.0$ & $11-23$ & 17 & $17 \pm 6$ \\
\hline 30 & $26-39$ & 32.5 & $32.5 \pm 6.5$ & $10-23$ & 16.5 & $16.5 \pm 6.5$ \\
\hline 33 & $27-39$ & 33.0 & $33.0 \pm 6.0$ & $9-21$ & 15 & $15 \pm 6$ \\
\hline
\end{tabular}

Using the mean values shown in Table (2), the following equations summarize the relationships between $\mathrm{I}_{632.8}$ and $\mathrm{I}_{543.5}$ as a function of the pods age (A).

$\mathrm{I}_{632.8}=9.661+0.762 \mathrm{~A}, \mathrm{R}^{2}=0.863, \mathrm{~F}_{\text {Regression }}=6301$
$\mathrm{I}_{543.5}=32.770-0.570 \mathrm{~A}, \mathrm{R}^{2}=0.759, \mathrm{~F}_{\text {Regression }}=3151$ 


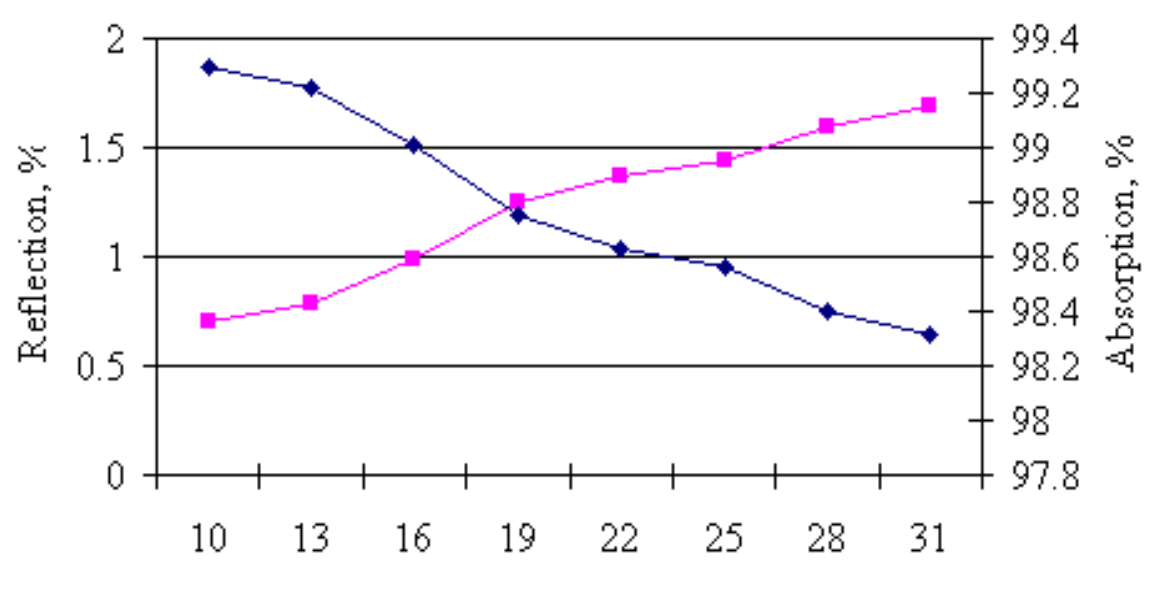

Age, day

$\rightarrow-$ Reflection $\% \rightarrow-$ Absorption $\%$

Fig. (4): Reflection and absorption percentages of green beans using $\mathrm{He}-\mathrm{Ne}$ laser $632.8 \mathrm{~nm}$

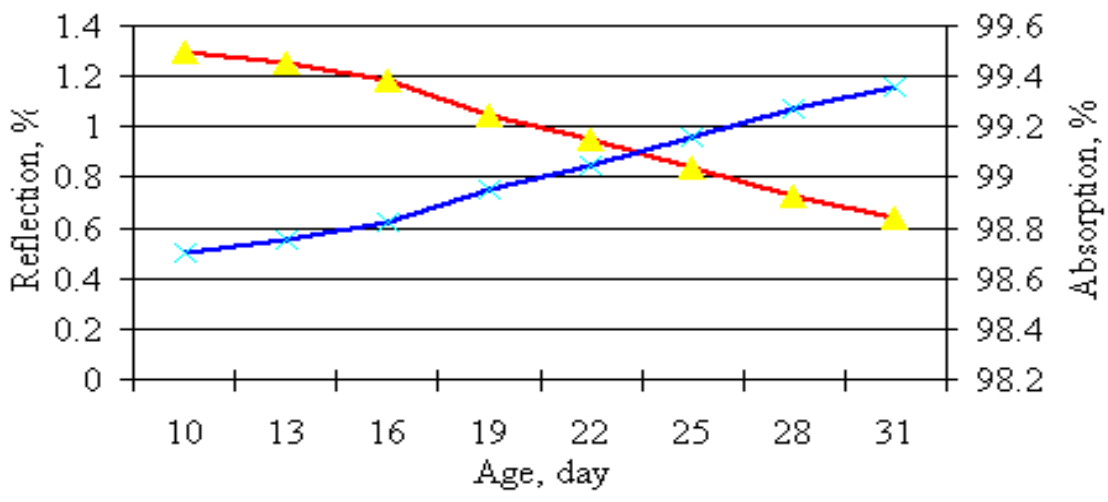

- -Reflection $\% \rightarrow$ Absorption $\%$

Fig. (5): Reflection and absorption percentages of green beans using He-Ne laser $543.5 \mathrm{~nm}$. 
The equations (7and 8) indicate that: the age affects the intensity of reflection by using laser at wavelength $632.8 \mathrm{~nm}$ more than the intensity of reflection by using laser at wavelength $543.5 \mathrm{~nm}$.

Figs (6 and 7) clear the relation between reflection and absorption percentage at different ages of green peas. Generally the percentages of light absorption is very higher than the percentages of light reflection. It is noticed that, when the age of pods increased, the light intensity of reflection percentage increased by using laser at wavelength $632.8 \mathrm{~nm}$ but it decreased when using laser at wavelength $543.5 \mathrm{~nm}$. This means that, the values of laser light reflection percentage from first ages (the first appearance of the pods from their flowers) were higher than the values at last ages at wavelength $543.5 \mathrm{~nm}$. Meanwhile those values were smaller than the values at the last ages from the appearance of the flowers pods at wavelength $632.8 \mathrm{~nm}$ for both pods of green beans and sweet peas. Because laser beam at wavelength $543.5 \mathrm{~nm}$ is green color as the same color of pods at the first ages and different color of pods at the last ages (maturity stages). The laser beam at wavelength $543.5 \mathrm{~nm}$ gave a high reflection with the same color (green pods). Thus, the component of green color was the highest at the first ages of the pods then decreased gradually towards the last ages of the pods (maturity stages). So the HeNe laser with wavelength $632.8 \mathrm{~nm}$ is suitable laser resulting in high reflection from green bean and sweet pea pods at ages 22 and 18 days, respectively (optimal harvest time) from the appearance of the flower pods.

\section{Electrical Measurement:}

\section{1. green bean pods:}

The values of measured electrical signals from light reflection of pods of green bean pods are tabulated in Table (4). It is noticed that the values of electrical signals from reflection of $\mathrm{He}-\mathrm{Ne}$ laser with wavelength $632.8 \mathrm{~nm}$ are higher than the values of electrical signals from reflection of He-Ne laser with wavelength $543.5 \mathrm{~nm}$ at pods ages 10 to 31 days. Using the mean values shown in Table (4), the following general equations were deduced to express the relationships between electrical reflection- by using laser at wavelength $632.8 \mathrm{~nm}-\left(\mathrm{E}_{632.8}\right)$ and electrical 


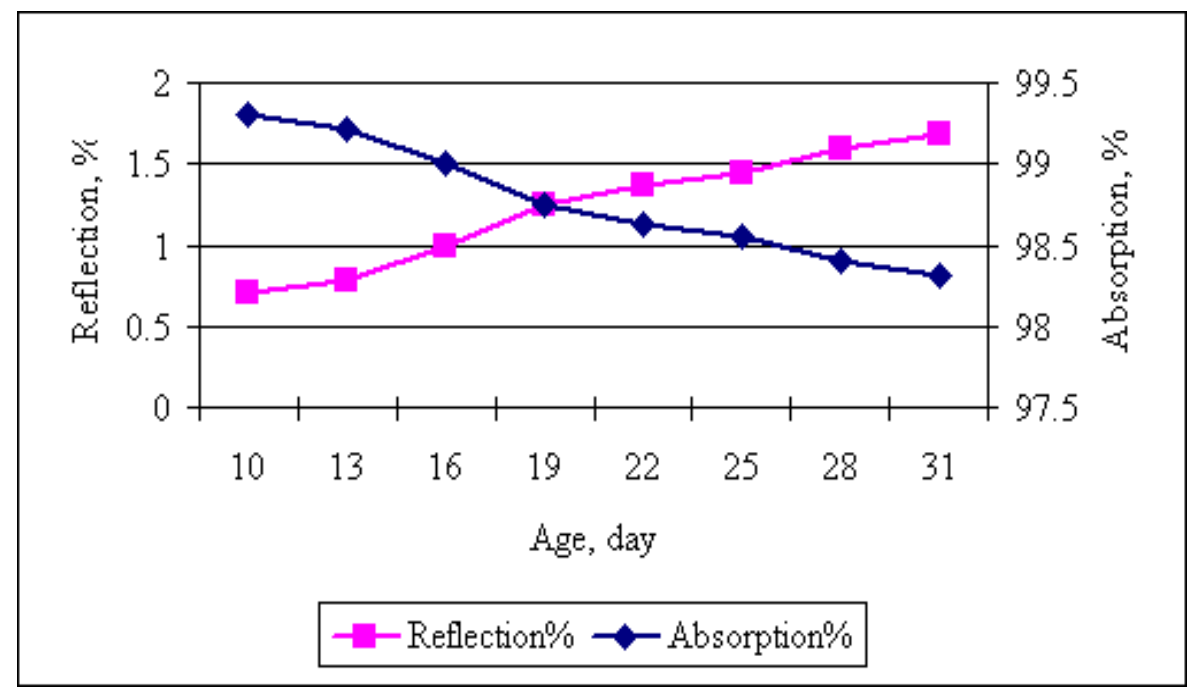

Fig. (6): Reflection and absorption percentages of sweet peas using He$\mathrm{Ne}$ laser 632.8nm.

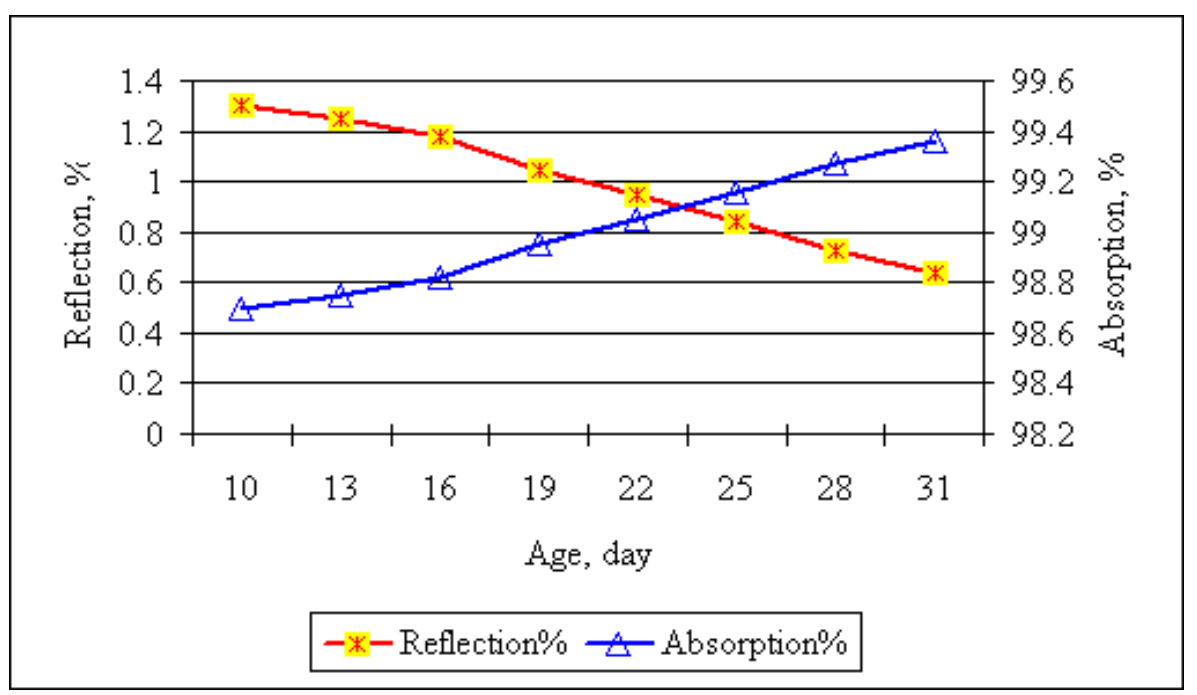

Fig. (7): Reflection and absorption percentages of sweet peas using He$\mathrm{Ne}$ laser $543.5 \mathrm{~nm}$. 
reflection -by using laser at wavelength $543.5 \mathrm{~nm}-\left(\mathrm{E}_{543.5}\right)$ for green bean pods at different ages from the appearance of the pods.

Table (4): The electrical reflection $(\mathrm{mV})$ from green bean pods at different ages using He-Ne laser with two wavelengths.

\begin{tabular}{|c||c|c|c|c|c|c||}
\hline \multirow{2}{*}{ Pods } & \multicolumn{5}{|c||}{ He-Ne laser } \\
\cline { 2 - 7 } $\begin{array}{c}\text { age, } \\
\text { day }\end{array}$ & $\begin{array}{c}\text { Range } \\
\text { mV }\end{array}$ & $\begin{array}{c}\text { Mean } \\
\text { value, } \\
\mathrm{mV}\end{array}$ & $\begin{array}{c}\text { Mean } \\
\text { electrical } \\
\text { reflections, } \\
\mathrm{mV}\end{array}$ & $\begin{array}{c}\text { Range, } \\
\mathrm{mV}\end{array}$ & $\begin{array}{c}\text { Mean } \\
\text { value, } \\
\mathrm{mV}\end{array}$ & $\begin{array}{c}\text { Mean } \\
\text { electrical } \\
\text { reflections, } \\
\mathrm{mV}\end{array}$ \\
\hline \hline 10 & $30-44$ & 37 & $37 \pm 7$ & $10.6-20.5$ & 15.55 & $15.55 \pm 4.95$ \\
\hline 13 & $39-53$ & 46 & $46 \pm 7$ & $9.9-19.9$ & 14.9 & $14.9 \pm 5$ \\
\hline 16 & $41-63$ & 52 & $52 \pm 11$ & $9.2-19$ & 14.1 & $14.1 \pm 4.9$ \\
\hline 19 & $40-72$ & 56 & $56 \pm 16$ & $8.5-18.7$ & 13.6 & $13.6 \pm 5.1$ \\
\hline 22 & $42-76$ & 59 & $59 \pm 17$ & $7.6-18.2$ & 12.9 & $12.9 \pm 5.3$ \\
\hline 25 & $46-82$ & 64 & $64 \pm 18$ & $6.4-17.8$ & 12.1 & $12.1 \pm 5.7$ \\
\hline 28 & $52-88$ & 70 & $70 \pm 18$ & $5.3-16.5$ & 10.9 & $10.9 \pm 5.6$ \\
\hline 31 & $55-95$ & 75 & $75 \pm 20$ & $3.8-13.3$ & 8.55 & $8.55 \pm 4.75$ \\
\hline \hline
\end{tabular}

For pods at 10 days(first age):

$\mathrm{E}_{632.8}=0.420 \mathrm{E}_{543.5}$

For pods at 22 days:

$\mathrm{E}_{632.8}=0.219 \mathrm{E}_{54}$

For pods at 31 days(last age):

$\mathrm{E}_{632.8}=0.114 \mathrm{E}_{543.5}$

Generally, the following equations summarize the relationships between $\mathrm{E}_{632.8}$ and $\mathrm{E}_{543.5}$ as functions of the pods age (A).

$\mathrm{E}_{632.8}=22.648+1.713 \mathrm{~A}, \mathrm{R}^{2}=0.761, \mathrm{~F}_{\text {Regression }}=2543$

$\mathrm{E}_{543.5}=18.276-0.282 \mathrm{~A}, \mathrm{R}^{2}=0.310, \mathrm{~F}_{\text {Regression }}=358$ 
The equations (12 and 13) indicate that: the age affects the electrical reflection by using laser at wavelength $632.8 \mathrm{~nm}$ more than the electrical reflection by using laser at wavelength $543.5 \mathrm{~nm}$.

Fig. (8) shows the comparison between electrical signal reflections for two wavelengths of green bean pods at different ages from the appearance of the flowers; an inverse relationship is noticed between the two curves. The values of $632.8 \mathrm{~nm}$ curve are higher than the values of $543.5 \mathrm{~nm}$ curve. They illustrate that when the pods age from the appearance of the pods from the flowers increase, the electrical signal reflection for He-Ne laser at wavelength $632.8 \mathrm{~nm}$ increases gradually from 37 to $75 \mathrm{mV}$. However, the electrical signal reflection for wavelength $543.5 \mathrm{~nm}$ decreased from 15.55 to $8.55 \mathrm{mV}$.

Figs. (9 and 10) show the comparison between light and electrical signal reflections from green bean's pods at different ages using He- Ne laser with two wavelengths. It is noticed that the quantity of electrical signals from laser reflection $(632.8 \mathrm{~nm})$ was higher than laser reflection $(543.5$ $\mathrm{nm})$. Moreover, the figures indicate that by increasing the quantity of optical reflection, the electrical signals increased using laser with wavelength $632.8 \mathrm{~nm}$. Meanwhile, by decreasing the light reflection, the electrical signal decreased using laser with wavelength $632.8 \mathrm{~nm}$.

\subsection{Sweet peas pods:}

The values of measured electrical signals from the reflection of laser beam for pods of sweet peas are tabulated in Table (5). The table illustrates the electrical signals from the reflection of laser beam which varied at different ages. The values of electrical signals from the reflection laser beam at wavelength $632.8 \mathrm{~nm}$ are higher than the values of reflected laser beam at wavelength $543.8 \mathrm{~nm}$ at pods ages 6 to 30 days.

Using the mean values shown in Table (5), the following equations summarize the relationships between $\mathrm{E}_{632.8}$ and $\mathrm{E}_{543.5}$ as functions of the pods age (A). 


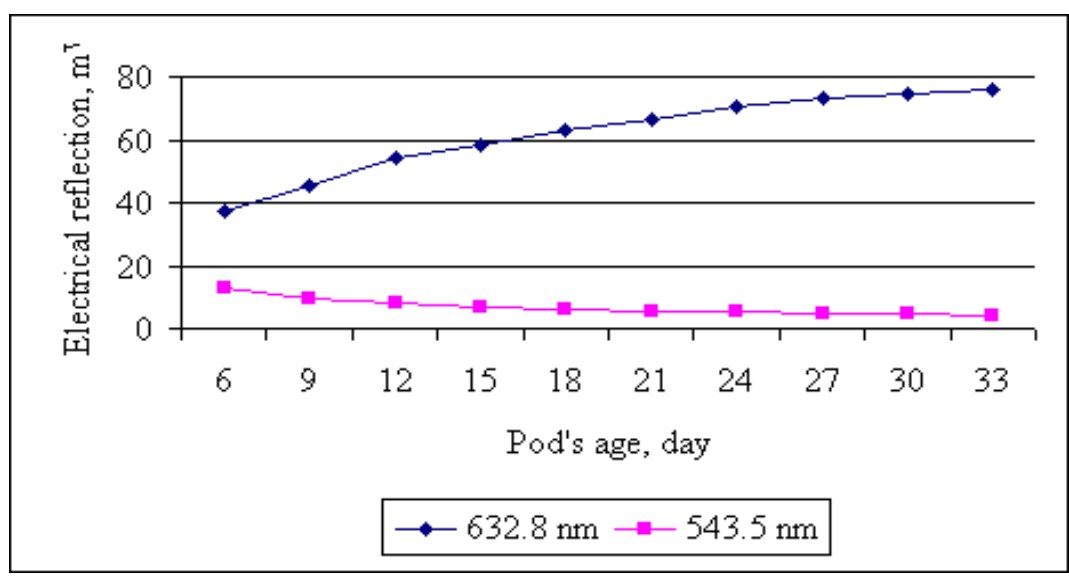

Fig.(8): Comparison between electrical signal reflections for two wavelengths from green bean pods at different ages.

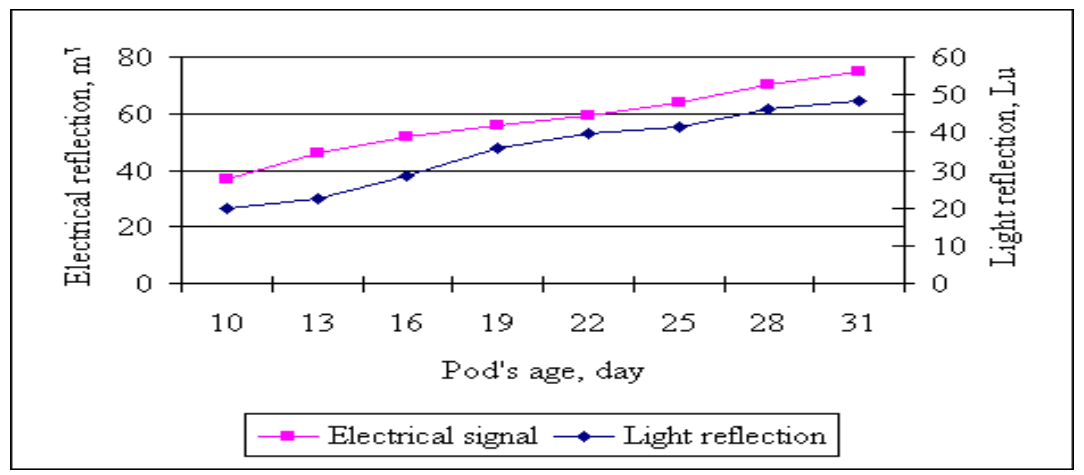

Fig. (9): Comparison between light and electrical signal reflections from green bean pods at different ages using laser $632.8 \mathrm{~nm}$.

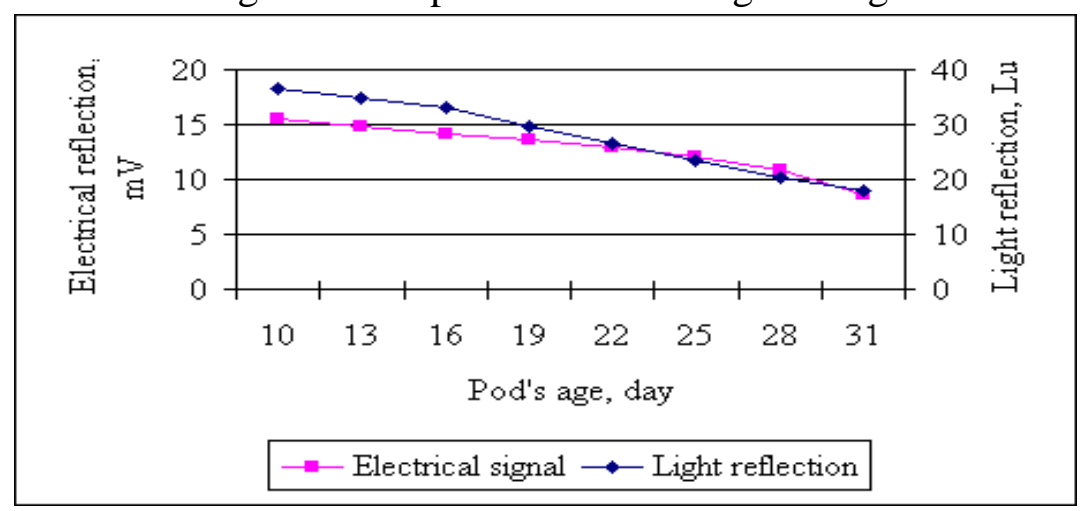

Fig. (10): Comparison between light and electrical signal reflections from green bean pods at different ages using laser $543.5 \mathrm{~nm}$. 
Table (5): The electrical reflection $(\mathrm{mV})$ from sweet peas pods at different ages using He-Ne laser with two wavelengths.

\begin{tabular}{|c|c|c|c|c|c|c|}
\hline \multirow{3}{*}{$\begin{array}{l}\text { Pods } \\
\text { age, } \\
\text { day }\end{array}$} & \multicolumn{6}{|c|}{ He-Ne laser } \\
\hline & \multicolumn{3}{|c|}{ (wavelength $632.8 \mathrm{~nm}$ ) } & \multicolumn{3}{|c|}{ (wavelength $543.5 \mathrm{~nm}$ ) } \\
\hline & $\begin{array}{c}\text { Range, } \\
\mathrm{mV}\end{array}$ & $\begin{array}{l}\text { Mean } \\
\text { value, } \\
\mathrm{mV}\end{array}$ & $\begin{array}{l}\text { Mean } \\
\text { electrical } \\
\text { reflections, } \\
\mathrm{mV}\end{array}$ & $\begin{array}{c}\text { Range, } \\
\mathrm{mV}\end{array}$ & $\begin{array}{c}\text { Mean } \\
\text { value, } \\
\mathrm{mV}\end{array}$ & $\begin{array}{c}\text { Mean } \\
\text { electrical } \\
\text { reflections, } \\
\mathrm{mV}\end{array}$ \\
\hline 6 & $29-46$ & 37.5 & $37.5 \pm 8.5$ & $\begin{array}{l}10.2- \\
15.5\end{array}$ & 12.85 & $12.85 \pm 2.65$ \\
\hline 9 & $36-55$ & 45.5 & $45.5 \pm 9.5$ & $8.1-11.5$ & 9.8 & $9.8 \pm 1.7$ \\
\hline 12 & $42-66$ & 54 & $54 \pm 12$ & $6.7-9.9$ & 8.3 & $8.3 \pm 1.6$ \\
\hline 15 & $47-70$ & 58.5 & $58.5 \pm 11.5$ & $4.8-9.2$ & 7 & $7 \pm 2.2$ \\
\hline 18 & $52-74$ & 63 & $63 \pm 11$ & $4.1-8.4$ & 6.25 & $6.25 \pm 2.15$ \\
\hline 21 & $56-77$ & 66.5 & $66.5 \pm 10.5$ & $3.6-7.8$ & 5.7 & $5.7 \pm 2.1$ \\
\hline 24 & $60-81$ & 70.5 & $70.5 \pm 10.5$ & $3.3-7.2$ & 5.25 & $5.25 \pm 1.95$ \\
\hline 27 & $62-84$ & 73 & $73 \pm 11$ & 3-6.6 & 4.8 & $4.8 \pm 1.8$ \\
\hline 30 & $64-85$ & 74.5 & $74.5 \pm 10.5$ & $2.8-6.4$ & 4.6 & $4.6 \pm 1.8$ \\
\hline 33 & $65-87$ & 76 & $76 \pm 11$ & $2.6-6.1$ & 4.35 & $4.35 \pm 1.75$ \\
\hline
\end{tabular}

$\mathrm{E}_{632.8}=35.531+1.360 \mathrm{~A}, \mathrm{R}^{2}=0.796, \mathrm{~F}_{\text {Regression }}=3892$

$\mathrm{E}_{543.5}=12.295-0.278 \mathrm{~A}, \mathrm{R}^{2}=0.728, \mathrm{~F}_{\text {Regression }}=2670$

Fig. (11) shows the comparison between electrical signal reflections for two wavelengths from sweet pea pods at different ages from the appearance of the pods from the flowers. An inverse relationship was noticed between the two curves. The values of the electrical reflections by using the laser at wavelength $632.8 \mathrm{~nm}$ are higher than the values of the electrical reflection at the other wavelength $(543.5 \mathrm{~nm})$. It was illustrated that when the pods age increased, the electrical signal reflection for $\mathrm{He}-\mathrm{Ne}$ laser at wavelength $632.8 \mathrm{~nm}$ increased gradually from 37.5 to $76 \mathrm{mV}$. However, the electrical signal reflection for wavelength $543.5 \mathrm{~nm}$ decreased from 12.85 to $4.35 \mathrm{mV}$. 
Figs. (12 and 13) show the relation between light and electrical signal reflections from sweet pea pods at different ages from the appearance of the pods from the flowers using $\mathrm{He}-\mathrm{Ne}$ laser at two wavelengths. It was noticed that the quantity of electrical signals from the reflection of laser $(632.8 \mathrm{~nm})$ was higher than that of the reflection of laser $(543.5 \mathrm{~nm})$. In addition, the figures indicate that by increasing the quantity of optical reflection, the electrical signals increased, using laser with wavelength $632.8 \mathrm{~nm}$. Meanwhile, by decreasing the light reflection, the electrical signal decreased using laser with wavelength $632.8 \mathrm{~nm}$.

This means that, for first age from the appearance of the pods from the flowers, the values of laser light reflection were higher than that of the last ages at wavelength $543.5 \mathrm{~nm}$.However, they were smaller than the values at the last age at wavelength $632.8 \mathrm{~nm}$ for both green bean and sweet pea pods. Thus, the component of green color was the highest at first age, this green component decreased gradually towards the last age. Therefore, the wavelength $543.5 \mathrm{~nm}$ was green color and it gave high reflection with the same color (pods).

From these, the He-Ne laser with wavelength $632.8 \mathrm{~nm}$ is the suitable laser resulting in high reflection from green bean and sweet pea pods at ages 22 and 18 days, respectively (optimal harvest time) from the appearance of the flowers pods.

\section{CONCOLUSION}

From the obtained results, the following conclusions can be made:

1- The values of light reflection intensity increased by using He-Ne laser (wavelength $632.8 \mathrm{~nm}$ ) from 15 to 59 Lux for ages of green bean pods from 10 to 31 days, respectively. Meanwhile, these values decreased by using He-Ne laser (543.5nm) from 46 to 10 Lux.

2- The values of light reflection intensity increased by using He-Ne laser (wavelength $632.8 \mathrm{~nm}$ ) from 10 to 39 Lux for ages of green peas pods from 6 to 33 days, respectively. Meanwhile, these values decreased by using He-Ne laser (543.5nm) from 35 to 9 Lux. 


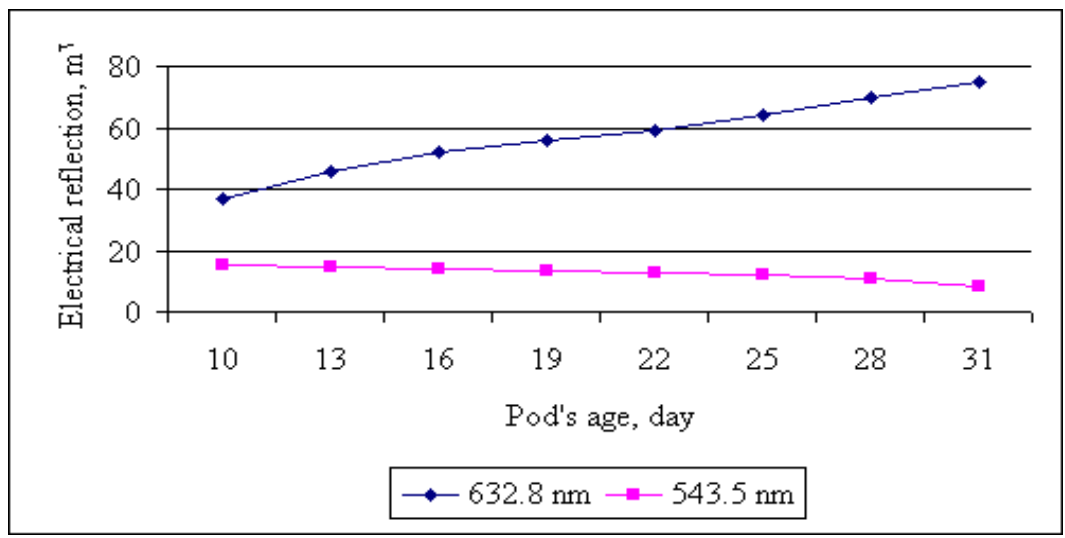

Fig. (11): Comparison between electrical signal reflections for two Wavelengths from sweet peas pods at different ages.

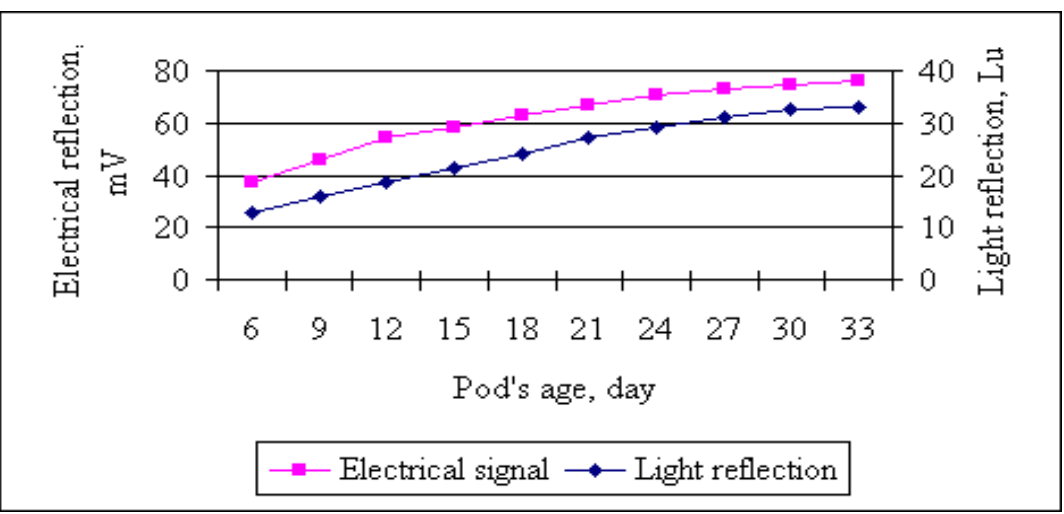

Fig. (12): Comparison between light and electrical signal reflections from sweet peas pods at different ages using laser $632.8 \mathrm{~nm}$.

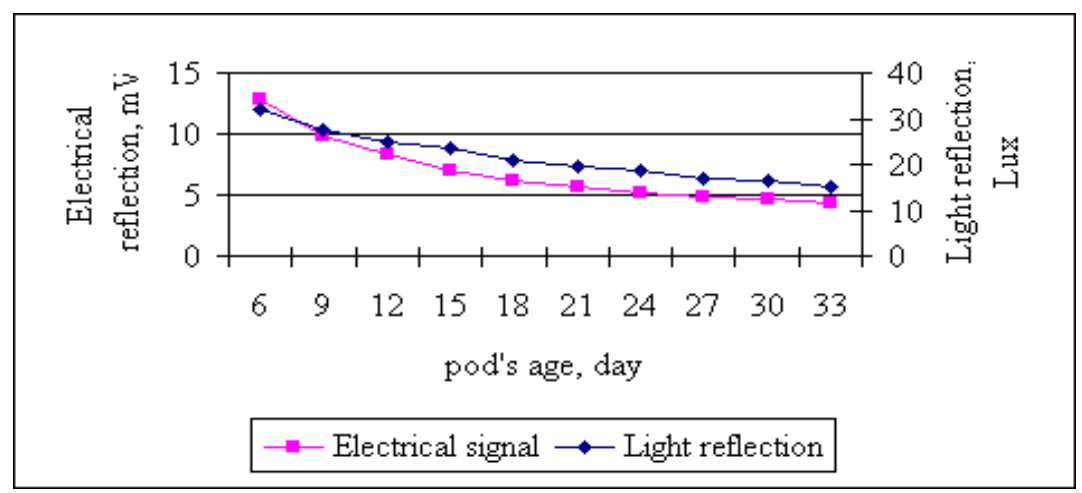

Fig. (13): Comparison between light and electrical signal reflections from sweet peas pods at different ages using laser $543.5 \mathrm{~nm}$. 
3- The values of electrical signals increased by using He-Ne laser (wavelength $632.8 \mathrm{~nm}$ ) from 30 to $95 \mathrm{mV}$ and ranged from 29 to 87 $\mathrm{mV}$ for green pea pods for ages from 6 to 33 days, respectively. But by using $\mathrm{He}-\mathrm{Ne}$ laser (wavelength $543.5 \mathrm{~nm}$ ), the values decreased from 20.5 to $3.8 \mathrm{mV}$ for green bean ages from 10 to 31 days, respectively. Meanwhile, these values decreased from 15.5 to 2.6 $\mathrm{mV}$ for green pea pods ages from 6 to 33 days.

4- There were relationships between intensity of light and electrical reflections by using two He-Ne laser as a function of the green beans and pea pods age. He-Ne laser with wavelength $632.8 \mathrm{~nm}$ is suitable for high reflection from green bean and sweet pea pods at ages (maturity stages) about 22 and 18 days, respectively (optimal harvest time) from the appearance of the flower pods.

\section{REFERENCE}

Ahn, S. S. and W. S. Moore. 1992. Endovascular surgery, Harcourt Brace Jovanovich Inc., London.:32-33.

Corgan, J. N. 2004. When to Harvest Vegetables. Coop. Ext. Serv., Coll. of Agric. and Home Eco.: 144-145.

El-Raie, A. E.; H. E. Hassan and A. A. Abd El-Rahman. 2005. Light and electrical reflections of visible laser for strawberry maturity stages. "Role and horizons of agricultural engineering in the contemporary world". The 13 th. Ann. Conf. Misr Soc. of Agric. Eng., 14-15 Dec. 2005: 538 - 552.

Gitelson A.; G. P. Keydan and M. N. Merzlyak. 2006. Three-band model for noninvasive estimation of chlorophyll, carotenoids, and anthocyanin contents in higher plant leaves. Geophysical Research Letters, Vol. 33, L11402, doi: 10.1029/2006 GL 026457.

Gitelson, A. and M.N. Merzlyak. 2004. Non-destructive assessment of chlorophyll, carotenoid and anthocyanin content in higher plant leaves: principle and algorithms. Remote Sensing for Agric. and the Env. Greece, Ella: 78-94. 
Hassan, H. E. 2002. Study of sorting and grading operations of Egyptian mature oranges using visible laser. Ph. D. thesis, Nat. Inst. of Laser Enhanced Sci. (NILES), Cairo Univ., ARE.:156-157.

Salunkhe, D. K. and Kadam, S. S. 1998. Handbook of vegetable. Production, composition, storage, and processing. Marcel Dekker, Inc. USA.: 437-462.

Slaughter, D. C. 1995. Nondestructive determination of internal quality in peach and nectarine. Trans.of the ASAE. Vol. 38(2): 617-623.

The center for occupational research and development. 1986. Introduction to lasers. The center for occupational res. and dev., USA.:77-78.

Zur, Y.; A.A. Gitelson; O. B. Chivkunova and M. N. Merzlyak. 2000. The spectral contribution of carotenoids to light absorption and reflectance in green leaves. $2^{\text {nd }}$. Int. conf. on Geospatial info. in agric. and forestry, Lake Buena Vista, Florida,: 10-12.

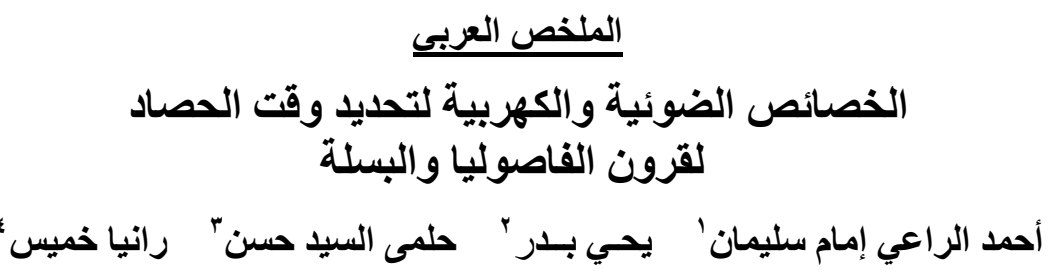

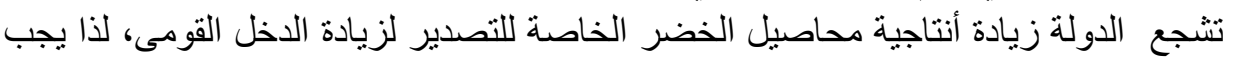

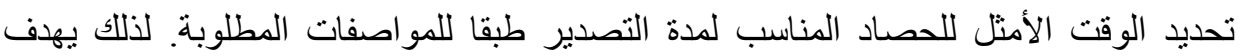

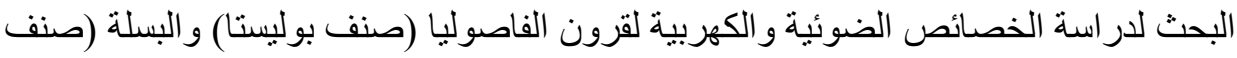

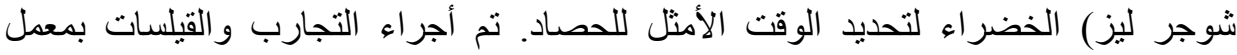

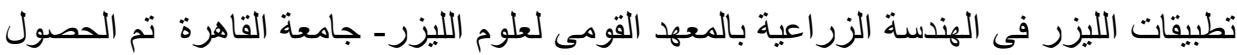

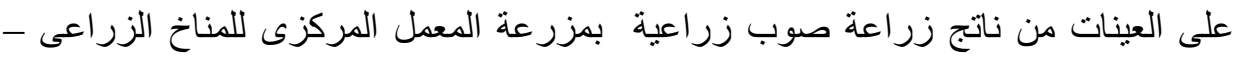

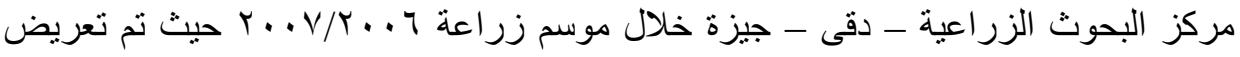

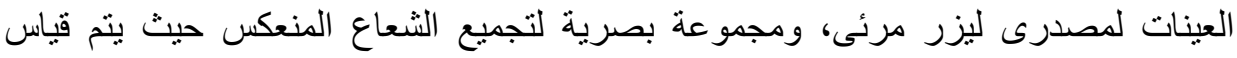
الكثافة الضوئية والكهربية، ويمكن ايجاز النتائج التى تم الحصول لئر عليها كالتالى:

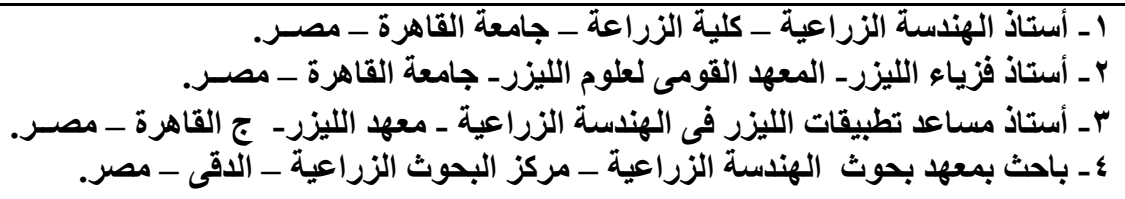




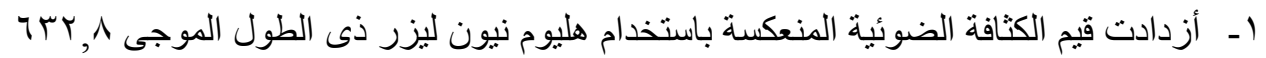

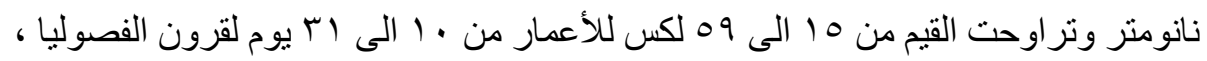

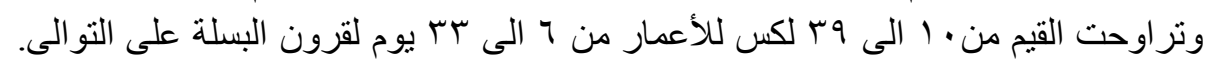

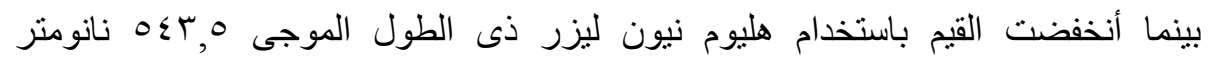

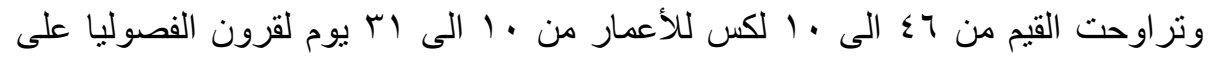

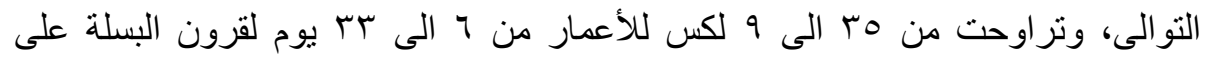

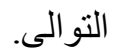

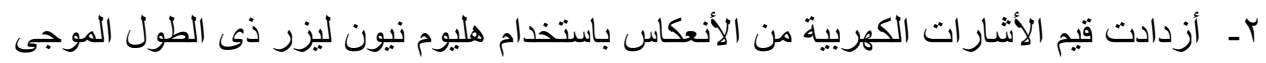

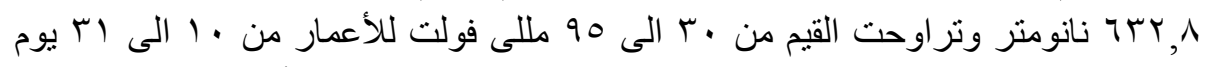

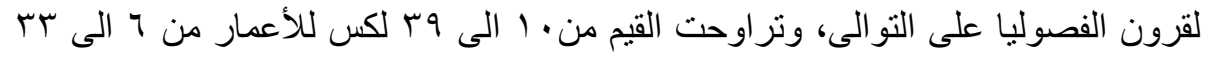

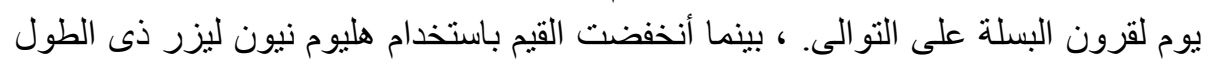

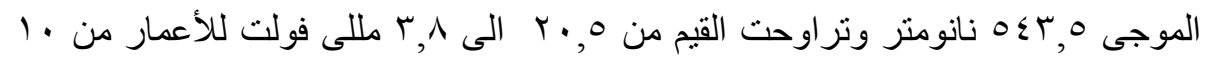

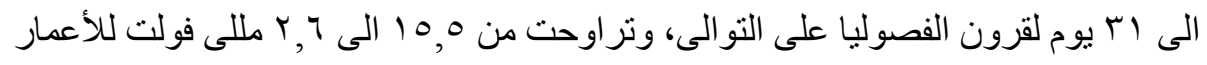

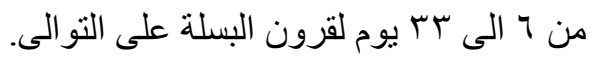

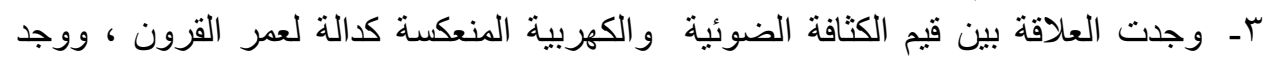

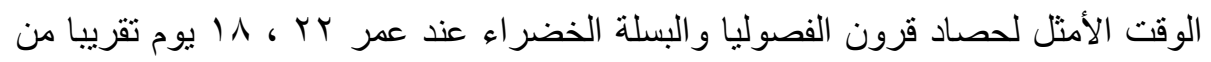

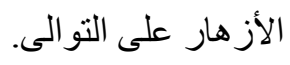

